\title{
Analysis of introns and promoters of L/M visual pigment genes in relation to deutan color-vision deficiency with an array of normal gene orders
}

\begin{abstract}
Hisao Ueyama ${ }^{1}$, Shoko Tanabe ${ }^{2}$, Sanae Muraki-Oda ${ }^{3}$, Shinichi Yamade ${ }^{3}$, Masahito Ohji ${ }^{3}$ and Iwao Ohkubo ${ }^{1}$
Among the 447 Japanese men with deutan color-vision deficiency that we analyzed, 61 had a normal order array of L/M pigment genes. Three of the 61 men had an exonic mutation, but the other 58 had no mutations even in the flanking introns of their $M$ genes. In these 58 men, 55 had a $-71 \mathrm{~A} \rightarrow C$ substitution in the $M$ gene. Two hypotheses were built up for the substitution: it is in linkage disequilibrium with a genuine cause of deficiency in the introns, or itself is the cause of the deficiency. For the first hypothesis, we sequenced entire regions of both the $L$ and $M$ genes in 30 color-normal Japanese men who had one each of the $L$ and $M$ genes to understand normal variations of the introns. Fifty-two already known and 15 newly identified polymorphic sites could be classified into three categories: those with no polymorphisms in the Japanese group, those essentially different between the $L$ and the $M$ genes, and the others. We then sequenced the entire region of the $M$ genes in 12 representative deutan individuals with a normal gene-order array but found no significant mutations. For the second hypothesis, we performed a reporter assay and found that the $\mathrm{M}$ gene promoter with $-71 \mathrm{C}$ had a $60-70 \%$ reduction in activity when compared to that with $-71 \mathrm{~A}$. These results suggest that the $-71 \mathrm{~A} \rightarrow \mathrm{C}$ substitution is not in linkage disequilibrium with an intronic mutation, but the substitution itself may affect the transcription of the $M$ gene, leading to deutan deficiency.
\end{abstract}

Journal of Human Genetics (2009) 54, 525-530; doi:10.1038/jhg.2009.73; published online 7 August 2009

Keywords: congenital color-vision deficiency; deutan; intron; promoter; visual pigment gene

\section{INTRODUCTION}

Dysfunction of cone cells in the retina has three classes: (1) rod monochromacy, in which none of the three types of cones, L (long wavelength-sensitive)-, $\mathrm{M}$ (middle wavelength-sensitive)- or S (short wavelength-sensitive)-cones, are functional; (2) cone monochromacy, in which only one type of cone is functional and (3) dichromacy and anomalous trichromacy, in which two types of cones are functional. The congenital color-vision deficiency that affects about $5 \%$ of Japanese men ${ }^{1}$ includes dichromacy and anomalous trichromacy. Protan deficiency, which is associated with a lack of $\mathrm{L}$ cones in the retina, is the less frequent deficiency (about 25\% of the cases) and involves both protanopia (dichromacy) and protanomaly (anomalous trichromacy). Deutan deficiency, which is associated with a lack of M cones in the retina, is the most frequent deficiency (about $75 \%$ of the cases) and involves both deuteranopia (dichromacy) and deuteranomaly (anomalous trichromacy). Tritan deficiency, which is associated with a lack of $S$ cones in the retina, is rare.

$\mathrm{L}$ cones express the $\mathrm{L}$ visual pigment and $\mathrm{M}$ cones express the $\mathrm{M}$ visual pigment. The genes for the $\mathrm{L}$ and $\mathrm{M}$ pigments are located in tandem on the human $\mathrm{X}$ chromosome, comprising an $\mathrm{L} / \mathrm{M}$ visual pigment gene array. ${ }^{2}$ In color-normal men, an L gene is present at the first position and an $\mathrm{M}$ gene is present at the second position in the array, ${ }^{3,4}$ referred to as $\mathrm{L}-\mathrm{M}$ in this study. As the $\mathrm{L}$ and $\mathrm{M}$ genes are very similar to each other, ${ }^{2}$ an unequal crossover between them tends to occur, which results in the formation of an array of single $\mathrm{L}, \mathrm{L}-\mathrm{L}$, single $\mathrm{M}$ or $\mathrm{M}-\mathrm{M}$, leading to color-vision deficiency. ${ }^{3,5-7}$

Of the 247 Japanese men with deutan deficiency that we studied, most of the arrays were either a single L gene or two (or more) L genes in tandem, but 37 men had normal gene-order arrays. ${ }^{8}$ Of these 37 men, two had a missense mutation of Asn94Lys ${ }^{9}$ or $A \arg 330 \mathrm{Gln}^{9}$ in the $\mathrm{M}$ gene, but the other 35 had no mutations in the exons or in the flanking introns of the $\mathrm{M}$ gene. The frequency of deutan individuals with a normal gene-order array, but without missense mutations was high $(14 \%, 35 / 247)$. Thirty-two men of the 35 men had a $-71 \mathrm{~A} \rightarrow \mathrm{C}$ substitution in the $\mathrm{M}$ gene promoter. ${ }^{8}$ All of these 32 men had the substitution in the $\mathrm{M}$ gene occupying the second position of the array. However, none of the 98 color-normal men with a two-gene array of L-M had the substitution. ${ }^{8}$ There were two possibilities about the $-71 \mathrm{~A} \rightarrow \mathrm{C}$ substitution in the etiology of color-vision deficiency. One was that the genuine cause of the deficiency is present in the introns and that the substitution is in linkage disequilibrium with it. The other was that the substitution itself is the cause of the deficiency.

${ }^{1}$ Department of Biochemistry and Molecular Biology, Shiga University of Medical Science, Seta, Otsu, Japan; ${ }^{2}$ Institute of Vision Research, Atsuta-ku, Nagoya, Japan and ${ }^{3}$ Department of Ophthalmology, Shiga University of Medical Science, Seta, Otsu, Japan

Correspondence: Dr H Ueyama, Department of Biochemistry and Molecular Biology, Shiga University of Medical Science, Seta, Otsu 520-2192, Japan.

E-mail: datt@belle.shiga-med.ac.jp

Received 20 April 2009; revised 30 June 2009; accepted 10 July 2009; published online 7 August 2009 
More than a half of the color-normal men have multiple downstream genes in an array, ${ }^{10-12}$ such as L-M-M, L-M-M-M, L-M-M$\mathrm{M}-\mathrm{M}$ and $\mathrm{L}-\mathrm{M}-\mathrm{L} .{ }^{13}$ Only the first two genes of the array were shown to be expressed in the retina, ${ }^{13}$ and the third and further downstream genes of the array are thought to be non-functional. On account of such complexities, normal variations within the introns of the $\mathrm{L} / \mathrm{M}$ visual pigment genes have not been fully characterized to date. In this study, we first examined both the $\mathrm{L}$ and $\mathrm{M}$ genes in 30 color-normal Japanese men with a two-gene array of $\mathrm{L}-\mathrm{M}$, to understand the normal variations, applying the longrange PCR method for the entire first gene (L) and for the entire downstream gene $(\mathrm{M})$. With regard to the polymorphic sites in the NCBI SNP Database and to those we had found, we examined both the $\mathrm{L}$ and $\mathrm{M}$ genes in 13 Caucasian and 13 Afro-American men. We then examined the introns of the $M$ gene in deutan individuals having a normal gene-order array. We compared the activities between $\mathrm{M}$ gene promoters with $-71 \mathrm{~A}$ or $-71 \mathrm{C}$ to identify which of the above hypotheses is correct.

\section{MATERIALS AND METHODS}

\section{Human participants}

The participants of this study had consulted the Japan Red Cross Nagoya First Hospital or the Shiga University of Medical Science Hospital regarding their color vision. Written informed consent was obtained from all participants and all study procedures were conducted according to the Declaration of Helsinki. This study was approved by the Medical Ethics Committee at the Shiga University of Medical Science (no. 13-7-1). They were diagnosed as protanor deutan deficient by examination with an anomaloscope (model I, Schmidt and Haensch, Berlin, Germany, and/or OT-II, Neitz Instruments, Tokyo, Japan). They also underwent other clinical tests including the Panel D-15 and Lantern tests. Male volunteers, whose color-vision status was confirmed to be normal by examination with Ishihara pseudoisochromatic plates and an anomaloscope (when necessary), also participated in this study. A blood sample drawn from each participant was used for extraction of genomic DNA.

To compare with the Japanese control and color-vision-deficient subjects profiles, genomic DNA from Caucasian and Afro-American men was purchased from the Coriell Institute for Medical Research (Camden, NJ, USA). The $\mathrm{L}$ and $\mathrm{M}$ genes of 13 Caucasian men with a two-gene $\mathrm{L}-\mathrm{M}$ array were analyzed (NA00536, NA00558, NA03657, NA06315, NA07491, NA07752, NA09549, NA09948, NA14492, NA12571, NA12691, NA12625 and NA12547). The $\mathrm{L}$ genes at the first position were analyzed in 13 Afro-American men (NA17101, NA17102, NA17103, NA17105-NA17109, NA17111, NA17114, NA17115, NA17117 and NA17125), but the M genes were analyzed in only four samples (NA17101, NA17105, NA17107 and NA17117), because only these four had two-gene L-M arrays. The color-vision status of these Caucasian and Afro-American men is unknown.

\section{L/M gene sequencing}

The gene number and L/M gene ratio were estimated as previously described. ${ }^{10}$ The entire first gene of the pigment gene array was amplified by PCR as previously described, using primers FG and E6. ${ }^{14}$ The entire second gene of the array was amplified by PCR as previously described, ${ }^{14}$ using primers SG (Table 1) and E6. The purified PCR products were used as the template in the second-round PCR for introns. The primers used are listed in Table 1 and the regions amplified are depicted in Figure 1. The PCR conditions were $94^{\circ} \mathrm{C}$ for $30 \mathrm{~s}, 55^{\circ} \mathrm{C}$ for $30 \mathrm{~s}$ and $72^{\circ} \mathrm{C}$ for $2.5 \mathrm{~min}$ for 25 cycles. The enzyme used was TaKaRa Taq DNA polymerase (Takara Bio, Otsu, Japan). Every portion of the second-round PCR products was sequenced. The sequencing primers listed in Table 1 as well as the primers for the second-round PCR were used for sequencing. The nucleotide sequence was determined using a BigDye Terminator v1.1 Cycle Sequencing Kit (Applied Biosystems, Foster City, CA, USA) in the ABI PRISM 3130xl Genetic Analyzer (Applied Biosystems).

\section{Promoter and enhancer assay}

The L/M gene promoter region was amplified by PCR from the genomic DNA of a color-normal participant, N102, who had a two-gene array of L-M and $-71 \mathrm{~A}$, and a deutan participant, A111, who had a two-gene array of L-M and $-71 \mathrm{C}^{8}$ The forward primers were FG; ${ }^{14}$ SG2 (Table 1); SG (Table 1); DG4 ${ }^{10}$ and PF- $1 .{ }^{8}$ The reverse primer for all of these reactions was PR. ${ }^{8}$ The enzyme used for this accurate PCR was KOD plus DNA polymerase (Toyobo, Osaka, Japan). The cycling parameters were $94^{\circ} \mathrm{C}$ for $30 \mathrm{~s}, 55^{\circ} \mathrm{C}$ for $30 \mathrm{~s}$ and $72^{\circ} \mathrm{C}$ for

Table 1 Primers used in PCR, sequencing and/or cloning

\begin{tabular}{|c|c|c|c|}
\hline Region & Primer & Position & Sequence $\left(5^{\prime} \rightarrow 3^{\prime}\right)$ \\
\hline \multicolumn{4}{|c|}{ For long-range $P C R$} \\
\hline & $S G$ & -748 (M gene) & AAAGCCTAACAATGTCCAGGG \\
\hline \multicolumn{4}{|c|}{ For second-round PCR } \\
\hline \multirow[t]{2}{*}{ |1-1: } & PF-2 & -128 & GAGGAGGAGGTCTAAGTCCC \\
\hline & I1R & $763808^{a}$ & TTGGTCTGGGCATTGAGTTTC \\
\hline \multirow[t]{2}{*}{ |1-2(L): } & $\mathrm{s} I 3$ & $763170^{a}$ & AATGTCGGGGTGGGTTTTT \\
\hline & LIR & $766158^{a}$ & CTAACCCCAATACCTCAGAAT \\
\hline \multirow[t]{2}{*}{ |1-2(M): } & $\mathrm{SI} 4$ & $767514^{a}$ & GAATCAGGGCTCAAATAAG \\
\hline & SI10 & $767661^{a}$ & CTTGAGGGGAAGACCACTA \\
\hline \multirow[t]{2}{*}{ I1-3(L): } & LIF & $766034^{a}$ & ATAATCATAATCAGGACAGCCGTCATA \\
\hline & $2 \mathrm{R}$ & $768411^{\mathrm{a}}$ & GAGCCTGGGCCCCGACTGGC \\
\hline \multirow[t]{2}{*}{ I1-3(M): } & SI9 & $767519^{a}$ & ССССАССТССТААТАССАТ \\
\hline & $2 \mathrm{R}$ & & \\
\hline \multirow[t]{2}{*}{ 12: } & $2 \mathrm{~F}$ & $768044^{a}$ & CGGTGCTGCAGCCCAGCTCC \\
\hline & 2 & exon 3 & TGCTCCAACCAAAGATGG \\
\hline \multirow[t]{2}{*}{ 13: } & $3 F$ & $770331^{a}$ & CCTTTGCTTTGGCTCAAAGC \\
\hline & $4 R$ & $772246^{a}$ & GACTCATTTGAGGGCAGAGCAGC \\
\hline \multirow[t]{2}{*}{ 14(L): } & $4 \mathrm{~F}$ & $771960^{a}$ & TCCTGGGTCACCCCACCCTGCA \\
\hline & 9 & L exon 5 & GCAGTACGCAAAGATCATCACC \\
\hline \multirow[t]{2}{*}{ 14(M): } & $4 \mathrm{~F}$ & & \\
\hline & 10 & M exon 5 & AAGCAGAATGCCAGGACCATC \\
\hline \multirow[t]{2}{*}{ 15(L): } & $5 \mathrm{LF}$ & L exon 5 & GGTGATGATCTTTGCGTACTGCG \\
\hline & E6 & exon 6 & GCAGTGAAAGCCTCTGTGACTT \\
\hline \multirow[t]{2}{*}{ I5(M): } & $5 \mathrm{MF}$ & $M$ exon 5 & GATGGTCCTGGCATTCTGCT \\
\hline & E6 & & \\
\hline
\end{tabular}

For sequencing

$\begin{array}{clll}\text { Intron 1: } & \text { S1F4 } & 762103^{\mathrm{a}} & \text { CGTAGATGAGTGTGTTCAC } \\ & \text { SI2 } & 762596^{\mathrm{a}} & \text { TGGTGCCTTCAAGAACATC } \\ & \text { SI5 } & 763851^{\mathrm{a}} & \text { ACCCTGCCTTCACCTATTGG } \\ & \text { SI6.5R } & 764904^{\mathrm{a}} & \text { GGACCTAAGAACAGAGAACCC } \\ & \mathrm{S} 16 & 764651^{\mathrm{a}} & \text { CTGCTGGGACCTGTTC } \\ & 1318 & 765309^{\mathrm{a}} & \text { TAATCTGCCAAAAACAATG } \\ \text { Intron 2: } & \text { SI11 } & 768682^{\mathrm{a}} & \text { ACAACCCCAGAACAGTAGG } \\ & \text { SI12 } & 769171^{\mathrm{a}} & \text { TGCCTCCCCACCACTCTTA } \\ & 3437 \mathrm{R} & 770316^{\mathrm{a}} & \text { TCCCACTGTCCTGCTTAGA } \\ \text { Intron 3: } & \text { SI14 } & 770846^{\mathrm{a}} & \text { AGAGGCTGCTTGGGTCATA } \\ & 4045 \mathrm{R} & 771806^{\mathrm{a}} & \text { ACCGTTGGGTAGGATTTG } \\ \text { Intron 4: } & \text { SI15 } & 772630^{\mathrm{a}} & \text { AAGGAGTGGACCCGAGAGT } \\ & \mathrm{SI16} & 772981^{\mathrm{a}} & \text { GCTTCGGCTGTATTAGTCT } \\ \text { Intron 5: } & 4952 & \text { exon 5 } & \text { TCTACAACCCCGTTATCTA } \\ & \text { SI19 } & 774695^{\mathrm{a}} & \text { CCAGTCCATCCCTTCCACT } \\ & 5960 & 775712^{\mathrm{a}} & \text { GGGCTGCCGTCACAAACTA }\end{array}$

For cloning

\section{SG2 -888 (M gene) GCCACGGACATCTCAGAC}

apositions, corresponding to the $5^{\prime}$-nucleotide of each primer, are shown by the numbers in the L gene of NCBI Nucleotide Database contig NT_025965. In the second-round PCR section, the upper primer is the forward one and the lower primer is the reverse one. In the sequencing section, ' $R$ ' following primer names indicates that the primer is a reverse one. 


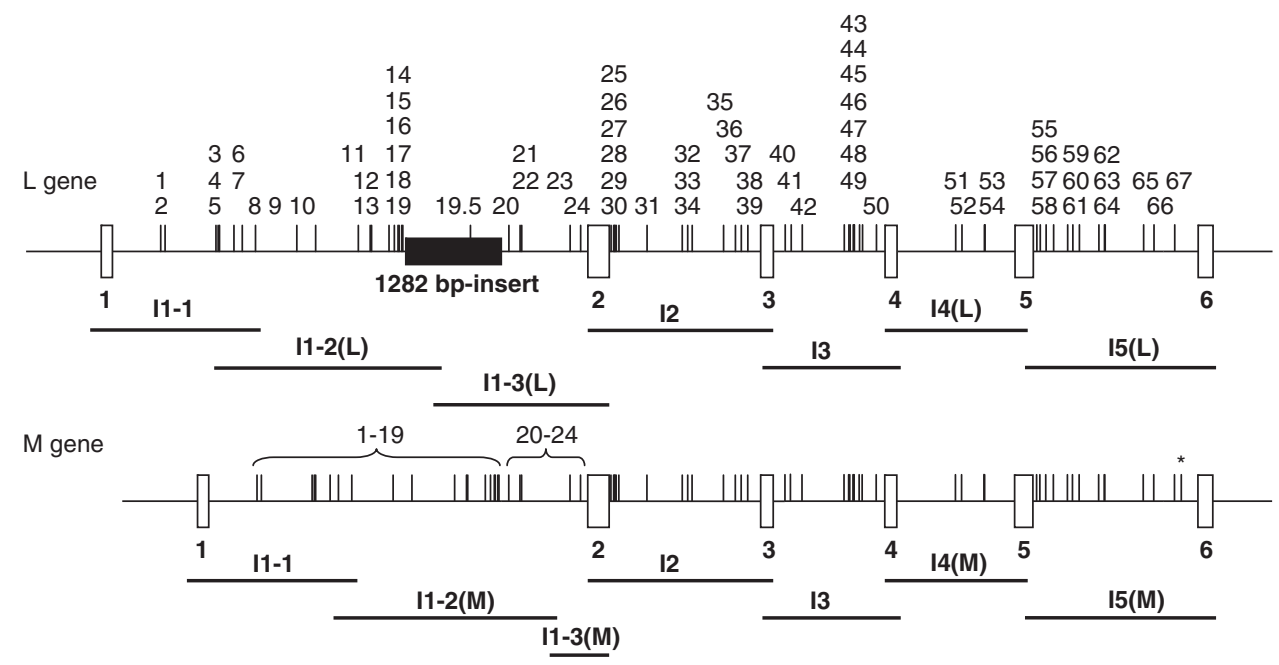

Figure 1 Polymorphic sites in the introns of the L/M visual pigment genes. Possible polymorphic sites are shown by vertical bars with the numbers $1-67$ above them. Open boxes represent the 6 exons with their numbers given below and the closed box represents the $1282 \mathrm{bp}$-insert present in L genes. Horizontal bars represent the regions amplified by the second-round PCR using the long-range PCR product for the entire $L$ gene or M gene as the templates. The asterisk $\left(^{*}\right)$ represents the position of a unique nucleotide found only in the M gene of the deutan participant, A315.

$1 \mathrm{~min}$ for 35 cycles. The products were cloned into the SmaI site of a pUC119 vector. The recombinant plasmids were digested by SacI and HincII, and the inserts were cloned between the SmaI and SacI sites of a luciferase reporter vector, pGL-2 (Promega, Madison, WI, USA). The integrity of the inserts was confirmed by sequencing.

The human retinoblastoma cells, WERI-Rb1, obtained from American Type Culture Collection (Manassas, VA, USA), were transfected with the plasmids using FuGene (Roche Diagnostics GmBH, Mannheim, Germany). The expression of endogenous $\mathrm{L}$ and $\mathrm{M}$ genes in WERI-Rb1 cells was confirmed by RT-PCR using the SuperScript One-Step RT-PCR System with Platinum Taq (Invitrogen, Carlsbad, CA, USA) and direct sequencing of the RT-PCR product $(461 \mathrm{bp})$. The primers used were $5^{\prime}$-GGATCACAGGTCTC TGGTCTC-3' corresponding to exon 3 and 5'-AAAGCATGCGAAGAAGG-3' corresponding to exon 5. Luciferase activity was measured using a Picagene luminescence kit (Wako, Osaka, Japan). As the SV40 promoter of the pSV- $\beta$ galactosidase plasmid (Promega) did not function in WERI cells, we cloned the 3738 bp HindIII-BamHI fragment containing $\beta$-galactosidase cDNA, between the HindIII and BamHI sites of the pCR3.1 vector (Invitrogen), to put the cDNA under the control of the CMV promoter. The resultant plasmid was used for standardization of the luciferase activities. $\beta$-Galactosidase activity was measured using the $\beta$-galactosidase enzyme assay system (Promega).

As we found a base substitution in intron 5 of the $M$ gene in A315, the genomic region containing introns 3-5 (as well as exons 3-6) was cloned into the BamHI site of the above promoter containing luciferase plasmids to detect enhancer activity. Transfections and luciferase assays were performed as described above.

\section{RESULTS}

\section{Deutan individuals with an array of normal gene orders}

We previously reported findings of 37 individuals with normal L/M gene-order arrays from a group of 247 Japanese men with deutan color-vision deficiency. ${ }^{8}$ We have since analyzed an additional group of 200 Japanese men with deutan deficiency identifying 24 individuals with normal gene-order arrays. Thirty-two of the 37 in the previous report ${ }^{8}$ and 23 of the 24 subjects in this study had a substitution of $-71 \mathrm{~A} \rightarrow \mathrm{C}$ in the $\mathrm{M}$ gene promoter at the second position of the array. Such a high proportion of $-71 \mathrm{~A} \rightarrow \mathrm{C}$ substitution (55 of 61 samples) suggests a close association of this substitution with deutan deficiency.

\section{Normal variations in $\mathrm{L} / \mathrm{M}$ gene introns}

We sequenced both the $\mathrm{L}$ and $\mathrm{M}$ genes in 30 color-normal Japanese men with a two-gene array of $\mathrm{L}-\mathrm{M}$, to learn the normal variations and then proceeded to analyze the $\mathrm{M}$ genes of the deutan individuals with an array of normal gene order.

Besides the 52 polymorphic sites in the introns of $\mathrm{L} / \mathrm{M}$ genes that had been deposited in the NCBI SNP Database, we found 15 novel polymorphic sites. The positions of these sites (total 67) are shown in Figure 1. The polymorphic site in the $1282 \mathrm{bp}$-insert in intron 1 (at position 766547 in the NCBI Nucleotide Database contig NT_025965; rs10482572 in the NCBI SNP Database) was numbered 19.5 in Figure 1, as the insert is present only in L genes. ${ }^{2,15}$ At Site 19.5, $G$ was seen more frequently than $A(A: G=5: 25)$ in the Japanese group. It was reported earlier that the Japanese population carried $\mathrm{L}$ genes without this insert at a frequency of $2 \%,{ }^{16}$ but all of the $30 \mathrm{~L}$ genes we examined had this insert.

Sites with no polymorphisms in the Japanese group. Table 2 summarizes the 23 sites in which no polymorphisms were detected in either the $\mathrm{L}$ or $\mathrm{M}$ genes of the 30 color-normal Japanese men. In the 13 Caucasian samples evaluated, Site 13 showed a polymorphism, but the other 22 sites did not (Table 2). In the 13 Afro-American samples studied, nine sites (Sites 1, 9, 22, 23, 24, 30, 34, 35 and 43) showed polymorphisms, but the other 14 sites did not. These results suggest that the $\mathrm{L} / \mathrm{M}$ pigment genes in individuals of African ancestry are more polymorphic than those in Japanese and Caucasians, which is consistent with the data on $236 \mathrm{~L}$ genes (introns 2-4 from 163 Africans and 74 non-Africans) by Verrelli and Tishkoff. ${ }^{17}$

Sites essentially different between $L$ and $M$ genes. Table 3 summarizes 15 sites that were essentially different between the $\mathrm{L}$ and $\mathrm{M}$ genes. They showed highly biased frequencies, which were opposite to each other, between the $\mathrm{L}$ and $\mathrm{M}$ genes in the Japanese group. Four sites (Sites 3, 15, 19 and 57) showed no polymorphisms within the L genes or within the $\mathrm{M}$ genes, but the nucleotides were different between these two genes. With regard to the other 11 sites, nucleotides that were more frequent in the $\mathrm{L}$ genes were less frequent in the $\mathrm{M}$ genes 
Table 2 Sites with no polymorphisms in the Japanese group

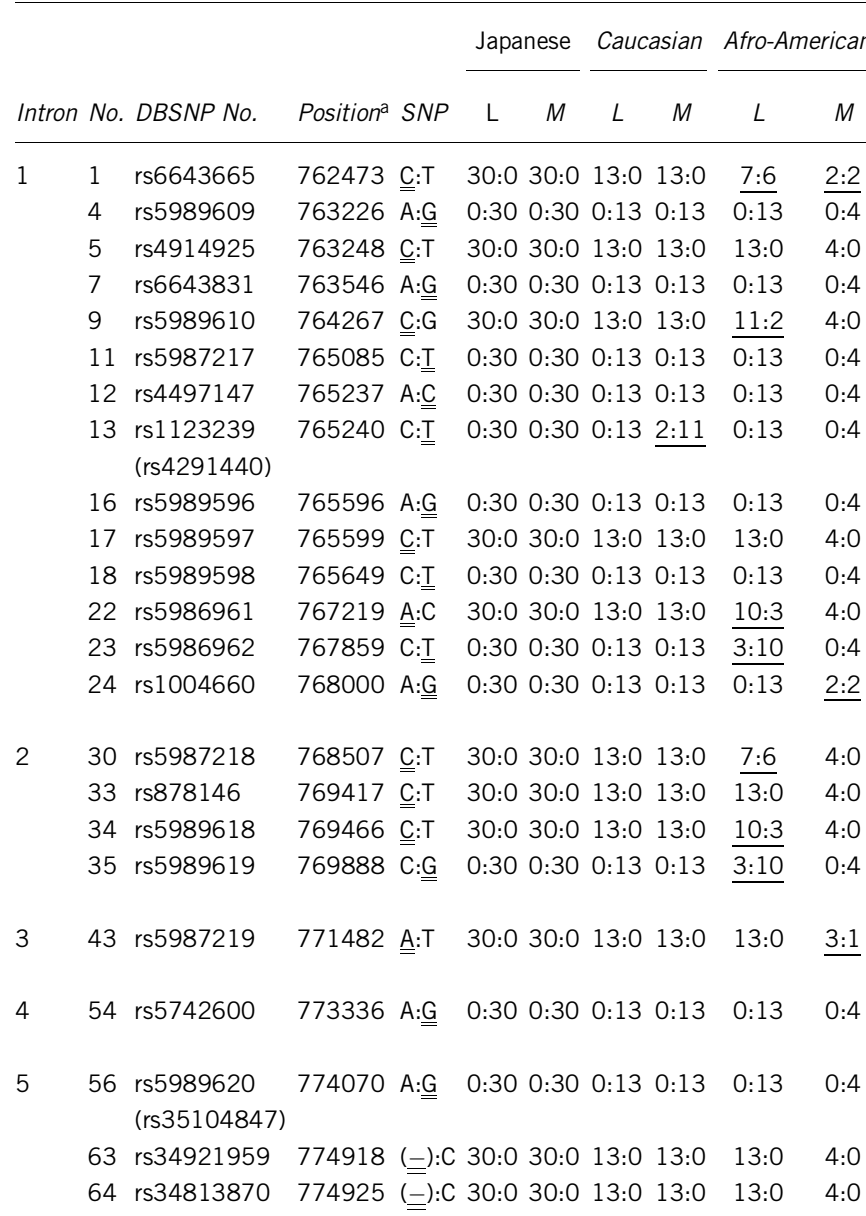

aPositions are those in the L gene of contig NT_025965 in the NCBI Nucleotide Database. Underlined are the sites showing polymorphisms. Doubly underlined nucleotides are those of the $\mathrm{M}$ gene in the 12 deutan individuals with a normal gene-order array and $-71 \mathrm{C}$.

(and vice versa). Such a tendency was also observed in the Caucasian group, with one exception (Site $2-\mathrm{M}$ gene, Table 3 ). However, it was obscure in the Afro-American group, again suggesting that $\mathrm{L} / \mathrm{M}$ pigment genes in individuals of African ancestry are more polymorphic than those of Japanese and Caucasians. Our data indicate that L gene- or M gene-specific nucleotides (especially at Sites 3, 15, $19,26,29,39$ and 57 (Table 3)) do exist in the introns $1-5$, as in the case of exons $2-5$.

Allele frequencies are known for only 2 of the 13 sites in the NCBI SNP Database: 0.410:0.590 (C/T) at Site 8, and 0.590:0.410 (A/C) at Site 29. Our results suggest that these frequencies were from both the $\mathrm{L}$ and $\mathrm{M}$ genes, that is, one nucleotide was from the $\mathrm{L}$ genes and the other was from the $\mathrm{M}$ genes.

The other sites. Table 4 summarizes the other 29 sites that were not classified into the previous two categories. Eight sites (Sites 6, 10, 20, $31,41,53,60$ and 62 ) showed polymorphisms only in the M gene, 8 sites (Sites 21, 28, 40, 48, 50, 51, 59, 66 and 67) showed polymorphisms only in the $\mathrm{L}$ gene, and the other 13 sites showed polymorphisms in both genes. The polymorphism at Site 53 was observed only in the Japanese subjects. Sites 46 and 47 were found to be in complete linkage disequilibrium in all the participants.
Table 3 Sites essentially different between $L$ and $M$ genes in the Japanese group

\begin{tabular}{|c|c|c|c|c|c|c|c|c|c|c|}
\hline \multirow[b]{2}{*}{ Intron } & \multirow[b]{2}{*}{ No. } & \multirow[b]{2}{*}{ DBSNP No. } & \multirow[b]{2}{*}{ Position $^{\mathrm{a}}$} & \multirow[b]{2}{*}{ SNP } & \multicolumn{2}{|c|}{ Japanese } & \multicolumn{2}{|c|}{ Caucasian } & \multicolumn{2}{|c|}{ Afro-American } \\
\hline & & & & & $L$ & $M$ & $L$ & $M$ & $L$ & $M$ \\
\hline \multirow[t]{6}{*}{1} & 2 & - & 762532 & $A: \underline{\underline{G}}$ & $0: 30$ & $23: 7$ & $0: 13$ & $6: 7$ & $1: 12$ & $2: 2$ \\
\hline & 3 & - & 763196 & $\underline{\underline{T}}:(-)$ & $0: 30$ & $30: 0$ & $0: 13$ & $13: 0$ & $1: 12$ & $3: 1$ \\
\hline & 8 & rs1573657 & 763722 & $\underline{\underline{C}}: T$ & $1: 29$ & $30: 0$ & $0: 13$ & $13: 0$ & $6: 7$ & $4: 0$ \\
\hline & 14 & $\begin{array}{l}\text { rs3890298 } \\
\text { (rs1984966) }\end{array}$ & 765482 & $\underline{\underline{C}}: \mathrm{G}$ & $27: 3$ & $4: 26$ & $9: 4$ & $3: 10$ & $8: 5$ & $2: 2$ \\
\hline & 15 & rs1467898 & 765553 & $A: \underline{\underline{G}}$ & $30: 0$ & $0: 30$ & $13: 0$ & $1: 12$ & $9: 4$ & $0: 4$ \\
\hline & 19 & rs2314756 & 765665 & $\underline{\underline{A}}: C$ & $0: 30$ & $30: 0$ & $0: 13$ & $13: 0$ & $4: 9$ & $4: 0$ \\
\hline \multirow[t]{5}{*}{2} & 26 & rs2071693 & 768441 & $\underline{\underline{C}}: \mathrm{T}$ & $1: 29$ & $30: 0$ & $1: 12$ & $13: 0$ & $3: 10$ & $4: 0$ \\
\hline & 27 & rs11492096 & 768447 & $A: \underline{\underline{G}}$ & 29:1 & $0: 30$ & $12: 1$ & $1: 12$ & $4: 9$ & $0: 4$ \\
\hline & 29 & rs916177 & 768500 & $\underline{\underline{A}}: C$ & $1: 29$ & $30: 0$ & $0: 13$ & $12: 1$ & $1: 12$ & $4: 0$ \\
\hline & 32 & rs3788802 & 769336 & $A: G$ & $23: 7$ & $4: 26$ & $12: 1$ & $2: 11$ & $11: 2$ & $2: 2$ \\
\hline & 39 & rs762841 & 770206 & $\mathrm{C}: \underline{\underline{T}}$ & $28: 2$ & $8: 22$ & $12: 1$ & $1: 12$ & $9: 4$ & $1: 3$ \\
\hline \multirow[t]{2}{*}{3} & 44 & rs2283755 & 771546 & $A: \underline{\underline{G}}$ & 29:1 & $0: 30$ & $9: 4$ & $0: 13$ & $7: 6$ & $0: 4$ \\
\hline & 45 & rs2283756 & 771561 & $\underline{\underline{C}}: \bar{T}$ & $1: 29$ & $28: 2$ & $4: 9$ & $13: 0$ & $\overline{6: 7}$ & $4: 0$ \\
\hline 4 & 52 & rs2157087 & 773035 & $A: \underline{\underline{G}}$ & $26: 4$ & $0: 30$ & $10: 3$ & $3: 10$ & $6: 7$ & $0: 4$ \\
\hline 5 & 57 & rs35520699 & 774146 & $A: \underline{\underline{G}}$ & $30: 0$ & $0: 30$ & $12: 1$ & $0: 13$ & $11: 2$ & $0: 4$ \\
\hline
\end{tabular}

aPositions are those in the L gene of contig NT_025965 in the NCBI Nucleotide Database. Underlined are the sites that did not show a biased frequency of polymorphisms. Doubly underlined nucleotides are those of the $\mathrm{M}$ gene in the 12 deutan individuals with a normal gene-order array and $-71 \mathrm{C}$. At Site 32 one individual had G but the other 11 had A.

Analysis of $\mathrm{M}$ gene introns in 12 representative deutan individuals Entire region of the $\mathrm{M}$ gene from 12 representative deutan individuals with a two-gene array of $\mathrm{L}-\mathrm{M}$ and $-71 \mathrm{C}$ was sequenced. We found a base substitution $(\mathrm{C} \rightarrow \mathrm{G}$ ) in intron 5 (at position 813064 in the NCBI Nucleotide Database contig NT_025965, * in Figure 1) in only one individual (A315). Eleven of the 12 deutan individuals showed the same nucleotide at each of the 67 polymorphic sites we examined, that is, they had one particular haplotype in common. These nucleotides are shown in Tables $2-4$ by double underlines. As the haplotype was also found in 4 of the 30 color-normal Japanese individuals, the haplotype was thought to be not deleterious for expression of the $\mathrm{M}$ gene concerned. One deutan individual (A81) had a haplotype that was different from those of the other 11, but the difference was small; it differed at only three positions, at Sites 32 (M-type G in A81 and L-type A in the others), 36 (A in A81 and G in the others) and 38 ( $\mathrm{G}$ in $\mathrm{A} 81$ and $\mathrm{T}$ in the others).

\section{Effect of $-71 \mathrm{~A}$ and $-71 \mathrm{C}$ on promoter activity}

Figure 2 summarizes the results of the luciferase reporter assay. In the L gene promoter, two constructs $(-819$ to +41 and -190 to +41$)$ showed no difference in their activity, suggesting that there are no potent cis-elements for transcription between -819 and -190 of the first gene promoter. This result is compatible with those of Shaaban and Deeb, ${ }^{18}$ who showed that a construct of -3624 to +41 did not show higher promoter activity than that of -190 to +41 . The $\mathrm{L}$ gene promoter $(-190$ to +41$)$ was at approximately $40 \%$ of the level observed for the $\mathrm{M}$ gene promoter $(-190$ to +41$)$ with $-71 \mathrm{~A}$, which is also compatible with their results. ${ }^{18}$ We examined the $\mathrm{M}$ gene promoter up to -888 , because Shaaban and Deeb ${ }^{18}$ examined only up to -190 . The activity was approximately the same at the four points 
Table 4 Polymorphic sites in either of $L$ and $M$ genes or in both genes

Afro-

Japanese Caucasian American

\begin{tabular}{|c|c|c|c|c|c|c|c|c|c|c|}
\hline \multirow[b]{2}{*}{ Intron } & \multirow[b]{2}{*}{ No. } & \multirow[b]{2}{*}{ DBSNP No. } & \multirow[b]{2}{*}{ Position ${ }^{\mathrm{a}}$} & \multirow[b]{2}{*}{ SNP } & \multicolumn{2}{|c|}{ Japanese } & \multicolumn{2}{|c|}{ Caucasian } & \multicolumn{2}{|c|}{ American } \\
\hline & & & & & $L$ & $M$ & $L$ & $M$ & $L$ & $M$ \\
\hline \multirow[t]{4}{*}{1} & 6 & rs2157098 & 763445 & $\underline{\underline{A}}: G$ & $0: 30$ & $15: 15$ & $0: 13$ & $7: 6$ & $2: 11$ & $3: 1$ \\
\hline & 10 & - & 764528 & $\underline{\underline{C}: T}$ & $0: 30$ & $20: 10$ & $0: 13$ & $4: 9$ & $0: 13$ & $1: 3$ \\
\hline & 20 & - & 767048 & $\underline{\underline{G}}: \mathrm{T}$ & $0: 30$ & $6: 24$ & $3: 10$ & $3: 10$ & $0: 13$ & $0: 4$ \\
\hline & 21 & - & 767204 & $(\underline{\underline{+}}):(-)$ & $29: 1$ & $30: 0$ & $11: 2$ & $13: 0$ & $13: 0$ & $4: 0$ \\
\hline
\end{tabular}

$\begin{array}{llllllllll}25 & \text { rs2071692 } & 768412 & \underline{\underline{A}}: G & 1: 29 & 14: 16 & 0: 13 & 9: 4 & 7: 6 & 2: 2 \\ 28 & - & 768450 & \underline{\underline{C}}: G & 29: 1 & 30: 0 & 11: 2 & 13: 0 & 13: 0 & 4: 0 \\ 31 & - & 768876 & \underline{\underline{C}}: G & 30: 0 & 16: 14 & 12: 1 & 9: 4 & 13: 0 & 3: 1 \\ 36 & \text { rs2187696 } & 770036 & \text { A:G } & 29: 1 & 26: 4 & 13: 0 & 11: 2 & 8: 5 & 4: 0 \\ 37 & \text { rs4592198 } & 770115 & \underline{\underline{C}}: G & 23: 7 & 18: 12 & 7: 6 & 6: 7 & 10: 3 & 2: 2 \\ 38 & \text { rs4578146 } & 770205 & \text { G:T } & 28: 2 & 18: 12 & 12: 1 & 5: 8 & 9: 4 & 2: 2\end{array}$

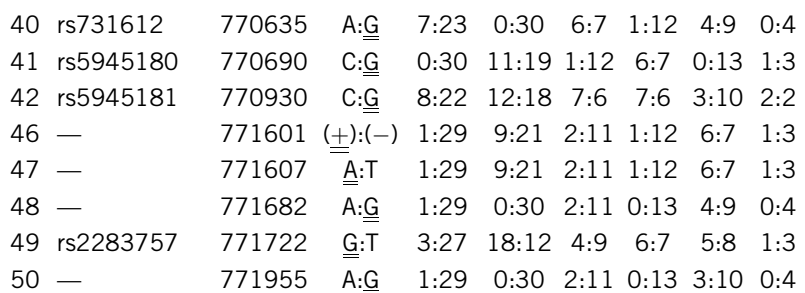

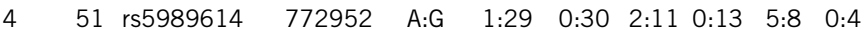

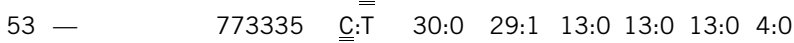

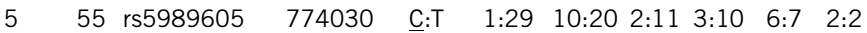
(rs35315068)

58 rs34520628 $774240 \quad \underline{\underline{C}}: \mathrm{T} \quad 29: 1 \quad 11: 19 \quad 12: 1 \quad 4: 9 \quad 7: 6 \quad 1: 3$ (rs5742601)

$774425 \quad$ C:T $\quad 1: 29 \quad 0: 30 \quad 2: 11 \quad 0: 13 \quad 3: 10 \quad 0: 4$

60 rs35450739 $774495 \quad$ C: $\underline{\underline{T}} \quad 30: 0 \quad 18: 12 \quad 12: 1 \quad 11: 2 \quad 13: 0 \quad 4: 0$

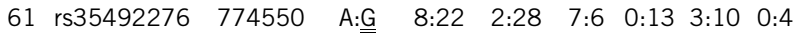

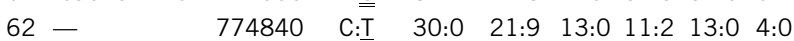

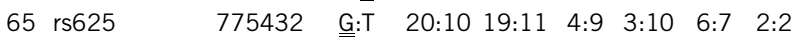

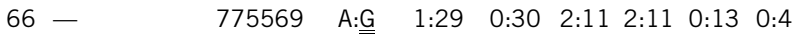

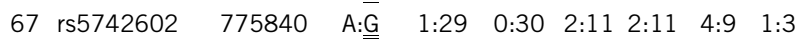

aPositions are those in the L gene of the contig NT_025965 in the NCBI Nucleotide Database. Doubly underlined nucleotides are those of the $M$ gene in the 12 deutan individuals with a noubly underlined nucleotides are those of the $M$ gene in the 12 deutan individuals respectively, but the other 11 had $\mathrm{G}$ and $\mathrm{T}$, respectively.

examined ( -888 to, -748 to, -317 to, and -190 to +41 ), and the $\mathrm{M}$ gene promoter with $-71 \mathrm{C}$ was always weak $(30-40 \%)$ compared to that with $-71 \mathrm{~A}$ (Figure 2). The $\mathrm{M}$ gene promoter with $-71 \mathrm{C}$ showed an activity similar to that shown by the $\mathrm{L}$ gene promoter.

\section{DISCUSSION}

The $-71 \mathrm{~A} \rightarrow \mathrm{C}$ substitution in the $\mathrm{M}$ gene promoter has been frequently found in deutan individuals with an array of normal L-M gene orders. The substitution may be in linkage disequilibrium with a mutation in the intron, or the substitution itself may cause the deficiency. We analyzed introns $1-5$ of the $M$ genes in 12 representative deutan individuals but found only 1 base substitution, $C \rightarrow G$ in intron 5 , in one individual. The substitution in its context was from -GGCCTTCTT- to -GGCGTTCTT-. The altered sequence is unlikely to serve as a novel $5^{\prime}$ splice site, because it has no resemblance to the $5^{\prime}$ splice site consensus sequence, MAG|GTRAGT. ${ }^{19}$ We examined the genomic region containing introns $3-5$ (from a color-normal man) to determine whether the region contains regulatory sequences for transcription or not, but we did not detect an effect on the promoters. The possibility that the substitution has a negative effect on the efficiency of transcription was thus excluded. We think that this substitution has no significance in the etiology of color-vision deficiency but is a very rare normal variation. Eleven of the 12 deutan individuals with $-71 \mathrm{C}$ had the same haplotype with regard to the 67 polymorphic sites and the remaining individual had a haplotype quite similar to it. These results suggest a founder effect, and the cause for their deutan deficiency is expected to be common among them. We have found no mutual aberrations in their $\mathrm{M}$ genes except $-71 \mathrm{C}$.

The activity of the $\mathrm{M}$ gene promoter with $-71 \mathrm{C}$ was approximately $40 \%$ of the level of the $M$ gene promoter with $-71 \mathrm{~A}$. Shaaban and Deeb $^{18}$ found that the $M$ gene promoter was 2-4 times more active than the $\mathrm{L}$ gene promoter, and suggested that the $\mathrm{M}$ gene promoter could have evolved to compensate for its longer distance from the locus-control region, which is located $3.1-3.7 \mathrm{~kb}$ upstream of the $\mathrm{L}$ gene, but $41.5-42.1 \mathrm{~kb}$ far from the $\mathrm{M}$ gene. Deletion of the locuscontrol region is known to cause S-cone monochromacy, in which neither the L- and $\mathrm{M}$ cones are functional. ${ }^{20,21}$ Therefore, the $40 \%$ activity in the $\mathrm{M}$ gene promoter with $-71 \mathrm{C}$ (a similar level to the $\mathrm{L}$ gene promoter) may be insufficient for the locus-control region to elicit efficient transcription of the $\mathrm{M}$ gene concerned. The $\mathrm{L} / \mathrm{M}$ cone ratio in the retina of color-normal individuals was estimated to be $0.39: 1-13.3: 1,22$ and $0.9: 1-14.8: 1,1.1: 1-25.7: 1$ or $1.1: 1-7.8: 1{ }^{23}$ These results suggest that $\mathrm{M}$ cones should account for at least $3.7 \%$ of the $\mathrm{L}$ and $\mathrm{M}$ cones for normal color vision. The $-71 \mathrm{~A} \rightarrow \mathrm{C}$ substitution may cause severe imbalance of an $\mathrm{L}$ and $\mathrm{M}$ cone ratio leading to deutan colorvision deficiency. The arrangement of $\mathrm{L}$ and $\mathrm{M}$ cones in the retina of the deutan individuals with $-71 \mathrm{C}$ should be investigated in future studies.

The normal gene-order array has been also found in Caucasian individuals with deutan deficiency. Deeb et al. ${ }^{5}$ reported it in 2 of 41 individuals studied who had deutan deficiency, but did not analyze their $\mathrm{M}$ genes in detail. Winderickx et al. ${ }^{24}$ reported one individual whose $\mathrm{M}$ gene had a missense mutation of Cys203Arg (in exon 4). Jagla et al. ${ }^{7}$ reported it in 2 of 27 individuals with deutan deficiency, but did not find any mutations in the promoter, exons or the exon-intron junctions of their $\mathrm{M}$ genes. Neitz et al. ${ }^{25}$ reported 10 cases in 73 deuteranopic individuals; eight of them had a Cys203Arg mutation in the $\mathrm{M}$ genes, one had a missense mutation of Pro187Ser (in exon 3) and the other had no obvious alterations in the $\mathrm{M}$ gene except for a unique haplotype in exon 3. Thus, the high frequency of the $-71 \mathrm{~A} \rightarrow \mathrm{C}$ substitution in the $\mathrm{M}$ gene promoter in deutan individuals with a normal gene-order array is thought to be unique to Japanese individuals with color-vision deficiency.

With regard to the $M$ gene promoter in deutan deficiency with a normal gene-order array, we sequenced up to -748 in 10 representative individuals, but did not find any alterations other than $-71 \mathrm{~A} \rightarrow \mathrm{C}$. Neitz et al. ${ }^{25}$ reported a total of four base substitutions in the downstream gene promoter of dichromatic individuals. They were: $-483 \mathrm{~T} \rightarrow \mathrm{C}$ (in the L2 gene of an L1-L2 array), $-425 \mathrm{G} \rightarrow \mathrm{A}$ (in the M2 gene of an M1-M2 array), $-71 \mathrm{~A} \rightarrow \mathrm{C}$ (in the M2 gene of an M1-M2 array) and $-21 \mathrm{G} \rightarrow \mathrm{A}$ (in the $\mathrm{L} 2$ of an L1-L2 array). The nucleotides at -483 and -425 are present in the Alu sequence, and the base substitutions at these sites may be normal variations. The $-71 \mathrm{~A} \rightarrow \mathrm{C}$ substitution is thought to have caused no transcription of the M2 gene, leading to the dichromacy phenotype (protanopia). Thus, the $-71 \mathrm{~A} \rightarrow \mathrm{C}$ substitution may also be important for an understanding of the discrepancy between the genotype of anomalous trichromacy and the phenotype of dichromacy. Between the promoters of the first gene and the downstream gene(s) of an L/M pigment gene array, there are 14 nucleotide differences. ${ }^{2,14}$ We have previously pointed out an 


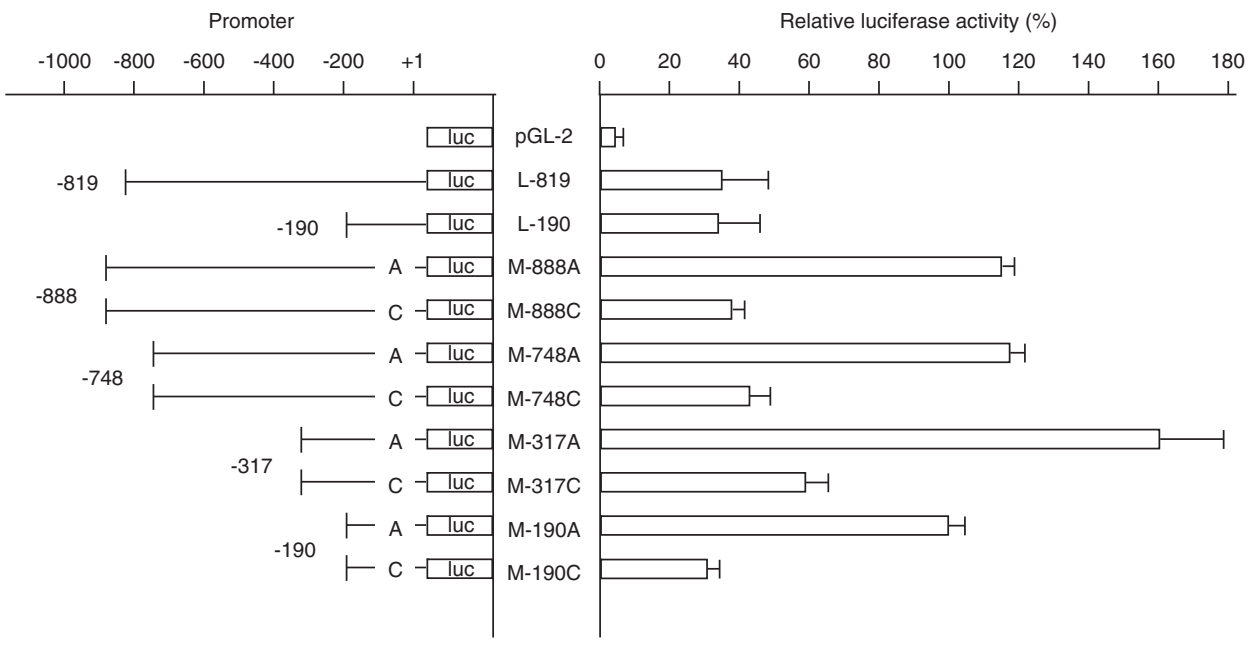

Figure 2 Promoter assay using the luciferase reporter system. Promoter regions of an L gene or an M gene were amplified by PCR from a color-normal man and the products were cloned into a luciferase plasmid, pGL-2. The same regions of an M gene were amplified by PCR from a male deutan participant who had an $\mathrm{M}$ gene with $-71 \mathrm{C}$, and the products were then cloned. Human retinoblastoma cells, WERI-Rb-1, were transfected with these plasmids and a $\beta$-galactosidase cDNA-containing plasmid for standardization. Cell extracts were prepared after 2 days and were used for the luciferase and $\beta$-galactosidase assays. Relative luciferase activity is shown as an average with its s.d. obtained from three independent experiments.

additional difference at -21 : the nucleotide is $\mathrm{G}$ in the first gene but $\mathrm{A}$ in the downstream genes. ${ }^{8}$ As we examined only Japanese individuals in the earlier study, we checked downstream genes of the Caucasian and Afro-American samples; all 26 participants had A at -21 . Therefore, the nucleotide at -21 of the downstream genes is $\mathrm{A}$, irrespective of the ethnic group.

\section{CONCLUSIONS}

From these results, we conclude that the $-71 \mathrm{~A} \rightarrow \mathrm{C}$ substitution is not in linkage disequilibrium with a mutation in the introns of the $\mathrm{M}$ gene, but the substitution itself may have affected the expression of the $\mathrm{M}$ gene concerned, leading to the deutan phenotype. Our data on the normal variations of the $\mathrm{L} / \mathrm{M}$ gene introns provide a useful resource for the future analysis of these genes.

\section{ACKNOWLEDGEMENTS}

We thank Mr Masashi Suzaki (Central Research Laboratory at the Shiga University of Medical Science) for his technical help (sequencing and primer extension). This work was supported in part by Grants-in Aid for Scientific Research from the Japan Society for the Promotion of Science (19614006 to HU and 17791228 to SM-O).

1 Ichikawa, K., Torii, F., Yasuma, T., Tanabe, S., Uesaki, H., Takayanagi, Y. et al. Frequency of congenital color-vision deficiency revealed by a group checkup for schoolchildren in Nagoya. (in Japanese). Rinsho-Ganka Iho 74, 959-962 (1980).

2 Nathans, J., Thomas, D. \& Hogness, D. S. Molecular genetics of human color vision: the genes encoding blue, green, and red pigments. Science 232, 193-202 (1986).

3 Nathans, J., Piantanida, T. P., Eddy, R. L., Shows, T. B. \& Hogness, D. S. Molecular genetics of inherited variation in human color vision. Science 232, 203-210 (1986).

4 Vollrath, D., Nathans, J. \& Davis, R. W. Tandem array of human visual pigment genes at Xq28. Science 240, 1669-1672 (1988).

5 Deeb, S. S., Lindsey, D. T., Hibiya, Y., Sanocki, E., Winderickx, J., Teller, D. Y. et al. Genotype-phenotype relationships in human red/green color-vision defects: molecular and psychophysical studies. Am. J. Hum. Genet. 51, 687-700 (1992).

6 Sharpe, L. T., Stockman, A., Jägle, H., Knau, H., Klausen, G., Reitner, A. et al. Red, green, and red-green hybrid pigments in the human retina: correlations between deduced protein sequences and psychophysically measured spectral sensitivities. J. Neurosci. 18, 10053-10069 (1998).

7 Jagla, W. M., Jägle, H., Hayashi, T., Sharpe, L. T. \& Deeb, S. S. The molecular basis of dichromatic color vision in males with multiple red and green visual pigment genes. Hum. Mol. Genet. 11, 23-32 (2002).
8 Ueyama, H., Li, Y.-H., Fu, G.-L., Lertrit, P., Atchaneeyasakul, L.-o., Oda, S. et al. An A$71 \mathrm{C}$ substitution in a green gene at the second position in the red/green visual-pigment gene array is associated with deutan color-vision deficiency. Proc. Natl. Acad. Sci. USA $100,3357-3362$ (2003).

9 Ueyama, H., Kuwayama, S., Imai, H., Tanabe, S., Oda, S., Nishida, Y. et al. Novel missense mutations in red/green opsin genes in congenital color-vision deficiencies. Biochem. Biophys. Res. Commun. 294, 205-209 (2002).

10 Ueyama, H., Tanabe, S., Muraki-Oda, S., Yamade, S. \& Ohkubo, I. Protan color vision deficiency with a unique order of green-red as the first two genes of a visual pigment array. J. Hum. Genet. 51, 686-694 (2006).

11 Drummond-Borg, M., Deeb, S. S. \& Motulsky, A. G. Molecular patterns of X chromosome-linked color vision genes among 134 men of European ancestry. Proc. Natl. Acad. Sci. USA 86, 983-987 (1989).

12 Hayashi, S., Ueyama, H., Tanabe, S., Yamade, S. \& Kani, K. Number and variations of the red and green visual pigment genes in Japanese men with normal color vision. Jpn. J. Ophthalmol. 45, 60-67 (2001).

13 Hayashi, T., Motulsky, A. G. \& Deeb, S. S. Position of a 'green-red' hybrid gene in the visual pigment array determines colour-vision phenotype. Nat. Genet. 22, 90-93 (1999).

14 Oda, S., Ueyama, H., Nishida, Y., Tanabe, S. \& Yamade, S. Analysis of L-cone/M-cone visual pigment gene arrays in females by long-range PCR. Vision Res. 43, 489-495 (2003).

15 Meagher, M. J., Jorgensen, A. L. \& Deeb, S. S. Sequence and evolutionary history of the length polymorphism in intron 1 of the human red photopigment gene. J. Mol. Evol. 43, 622-630 (1996).

16 Jørgensen, A. L., Deeb, S. S. \& Motulsky, A. G. Molecular genetics of X chromosomelinked color vision among populations of African and Japanese ancestry: high frequency of a shortened red pigment gene among Afro-Americans. Proc. Natl. Acad. Sci. USA 87, 6512-6516 (1990).

17 Verrelli, B. C. \& Tishkoff, S. A. Signatures of selection and gene conversion associated with human color vision variation. Am. J. Hum. Genet. 75, 363-375 (2004).

18 Shaaban, S. A. \& Deeb, S. S. Functional analysis of the promoters of the human red and green visual pigment genes. Invest. Ophthalmol. Vis. Sci. 39, 885-896 (1998).

19 Cartegni, L., Chew, S. L. \& Krainer, A. R. Listening to silence and understanding nonsense: exonic mutations that affect splicing. Nat. Rev. Genet. 3, 285-298 (2002).

20 Wang, Y., Macke, J. P., Merbs, S. L., Zack, D. J., Klaunberg, B., Bennett, J. et al. A locus control region adjacent to the human red and green visual pigment genes. Neuron 9, 429-440 (1992).

21 Nathans, J., Maumenee, I. H., Zrenner, E., Sadowski, B., Sharpe, L. T., Lewis, R. A. et al. Genetic heterogeneity among blue-cone monochromats. Am. J. Hum. Genet. 53, 987-1000 (1993).

22 Carroll, J., Neitz, J. \& Neitz, M. Estimates of L:M cone ratio from ERG flicker photometry and genetics. J. Vision 2, 531-542 (2002).

23 Knau, H., Kremers, J., Schmidt, H.-J., Wolf, S., Wissinger, B. \& Sharpe, L. T. M-cone opsin gene number does not correlate with variation in L/M-cone sensitivity. Vision Res. 42, 1888-1896 (2002).

24 Winderickx, J., Sanocki, E., Lindsey, D. T., Teller, D. Y., Motulsky, A. G. \& Deeb, S. S. Defective colour vison associated with a missense mutation in the human green visual pigment gene. Nat. Genet. 1, 251-256 (1992).

25 Neitz, M., Carroll, J., Renner, A., Knau, H., Werner, J. S. \& Neitz, J. Variety of genotypes in males diagnosed as dichromatic on a conventional clinical anomaloscope. Vis. Neurosci. 21, 205-216 (2004). 